\title{
Nitrogen Requirements for Vegetative Growth, Flowering, Seed Production, and Ramet Growth of Paphiopedilum armeniacum (Orchid)
}

\author{
Mou Zong-min, Yan Ning, Li Shu-yun, and Hu Hong ${ }^{1,2}$ \\ Key Laboratory of Economic Plants and Biotechnology, Kunming Institute of \\ Botany, Chinese Academy of Sciences, Kunming 650204, China
}

Additional index words. nitrogen availability, leaf traits, sexual reproduction, clonal reproduction, slipper orchid

\begin{abstract}
Paphiopedilum armeniacum S. C. Chen et F. Y. Liu is endemic to China and has great ornamental value. Little is known about its nutrient requirement for growth and reproduction after deflasking (transplantation of seedlings from culture vessels to pots). We studied the effects of adding nitrogen $(N)\left(0,105,210\right.$, and $\left.420 \mathrm{mg} \cdot \mathrm{L}^{-1}\right)$ on the vegetative growth and reproduction of $P$. armeniacum. $N$ enrichment improved leaf area and lengthened the leaf lifespan during the vegetative stage. The effects of $\mathrm{N}$ application on flower size were minor. The intermediate $N$ level of $210 \mathrm{mg} \cdot \mathrm{L}^{-1}(\mathrm{MN})$ increased the seed capsule weight, seed germination rate, and improved the growth of seedlings that developed from seeds of $\mathrm{MN}$-treated plants. $\mathbf{N}$ fertilizer exerted little influence on ramet emergence and ramet number per plant, but a low $N$ concentration of $105 \mathrm{mg} \cdot \mathrm{L}^{-1}$ promoted the leaf number and leaf area of ramets. Appropriate $\mathrm{N}$ levels for $P$. armeniacum in production and cultivation should be determined according to different production objectives.
\end{abstract}

Nitrogen is one of the major structural elements of organisms and it plays an important role in plant growth and reproduction. However, $\mathrm{N}$ deficiency is widespread in many ecosystems. An insufficient $\mathrm{N}$ supply reduces plant growth and leaf area and induces a decrease in the rate of photosynthesis and leaf $\mathrm{N}$ content (Boussadia et al., 2010; Chapin et al., 1988; Ferrar and Osmond, 1986; Munoz et al., 2005; Paul and Driscoll, 1997). Changing the $\mathrm{N}$ supplementation, sources, and applying its isotopes to plants are the commonly used methods of plant nutrient physiology to estimate biomass partition, reproductive allocation, and its roles in other physiological processes. The management of $\mathrm{N}$ is widely used in horticultural plants to optimize plant physiological characteristics, e.g., high-quality flowers and vigorous seeds, which are valuable in horticulture and seedling production, respectively. For ornamental orchids, $\mathrm{N}$ fertilization can help growers produce orchids more efficiently. The addition of $\mathrm{N}$ increases the number of leaves and flowers in Dendrobium nobile and $100 \mathrm{mg} \cdot \mathrm{L}^{-1} \mathrm{~N}$ is recommended for this

Received for publication 11 Jan. 2012. Accepted for publication 19 Mar. 2012

Research supported by the Western Light Foundation of The Chinese Academy of Sciences and Yunnan Social Development Science Program (No. 2007C0001Z, 2009CD116).

We thank Seng-yin Liu and Jia-lin Huang for their kind help.

${ }^{1}$ Professor.

${ }^{2}$ To whom reprint requests should be addressed; e-mail huhong@mail.kib.ac.cn. hybrid (Bichsel et al., 2008). Kubota et al. (2009) observed that $\mathrm{N}$ application increased biomass and leaf area of the current shoot in Odontioda and also increased the number of florets. The optimal amount of $\mathrm{N}$ application was $560 \mathrm{mg} /$ pot/year in the experiment. Increasing the $\mathrm{N}$ fertilizer from 50 to $200 \mathrm{mg} \cdot \mathrm{L}^{-1}$ increases flower count, flower number, stalk diameter and length, and leaf growth in a $\mathrm{Pha}$ laenopsis hybrid (Wang and Gregg, 1994). Lower $\mathrm{N}$ caused thinner bulb diameter and flower stalks, fewer roots and flowers, and advances in flowering date in Odontoglossum hybrid (Yoneda et al., 1999). Generally, the optimal applications of $\mathrm{N}$ vary among orchid species. When quantity of $\mathrm{N}$ surpasses a level, growth and flowering will be inhibited rather than promoted (Duan and Yazawa, 1995; Wang, 2003).

Paphiopedilum armeniacum is endemic to China and is well known as slipper orchid. It is famous for its golden yellow flowers and long flowering period. First class certificates have been awarded to $P$. armeniacum by the American Orchid Society, Royal Horticultural Society, and many others (Cribb, 1998). $P$. armeniacum is a hemiepiphyte on karst limestone cliffs and slopes in shady forests at elevations of 1400-2050 $\mathrm{m}$ in west Yunnan of China. The limestone area is characteristic of scarcity of soils and nutrient deficiency, especially in $\mathrm{N}$ and phosphorus (P). Meanwhile, vascular epiphytes are always limited by low nutrient availability in situ and point to $\mathrm{N}$ and/or P limitations (Zotz, 2004; Zotz and Asshoff, 2010). In general, the habitat of $P$. armeniacum is nutrient-poor. In the past decades, habitat destruction, overcollection, and restrict distributions are pushing this endangered genus to the verge of extinction (Tsi et al., 1999), and it is listed as a Convention on International Trade in Endangered Species of Wild Fauna and Flora Appendix I species. To date, the few studies on $P$. armeniacum are focusing on asymbiotic cultivation, conservation ecology, mycorrhizal fungi, molecular taxonomic identification, photosynthetic physiology, and morphological structure. However, little is known about its growth and reproduction after deflasking (transplantation of seedlings from culture vessels to pots). The study of nutrient physiology cannot only facilitate cultivation in horticulture, but could be helpful in conservation ecology of this endangered species.

The aims of this study were to evaluate the effects of $\mathrm{N}$ on the vegetative growth and reproduction of $P$. armeniacum to find the appropriate $\mathrm{N}$ level for cultivation and production.

\section{Materials and Methods}

Growth conditions and treatment. This study was performed in Kunming, Yunnan, China. In Nov. 2008, 200 5-year-old mature plants with visible flower buds and 3603 -yearold seedlings were randomly selected and transplanted into $0.785-\mathrm{L}$ plastic pots $(0.1 \mathrm{~m}$ wide and $0.1 \mathrm{~m}$ deep) filled with sphagnum moss, which is commonly used as potting material for orchids. All the materials were germinated from seeds by asymbiotic propagation (for 1 year) and grown in a greenhouse potting bark. Plants had four to six leaves and no ramets. These plants were divided into four groups, respectively, by a completely random design and then tagged with numbered tags. All plants were maintained in the greenhouse under a natural light source, at a controlled temperature $\left(24 / 18{ }^{\circ} \mathrm{C}\right.$, day/night), and watered as needed. Two weeks later, the plants of the four groups were grown at one of four $\mathrm{N}$ levels: $0 \mathrm{~N}(0$ $\left.\mathrm{mg} \cdot \mathrm{L}^{-1}\right), \mathrm{LN}\left(105 \mathrm{mg} \cdot \mathrm{L}^{-1}\right), \mathrm{MN}\left(210 \mathrm{mg} \cdot \mathrm{L}^{-1}\right)$, and $\mathrm{HN}\left(420 \mathrm{mg} \cdot \mathrm{L}^{-1}\right)$. The $\mathrm{N}$ levels were generated by applying $50 \mathrm{~mL}$ Hoagland's solution (Hoagland and Arnon, 1950) with no $\mathrm{N}, 50 \% \mathrm{~N}, 100 \% \mathrm{~N}$, and $200 \% \mathrm{~N}$ at the beginning of each month from Nov. 2008 to Aug. 2009. $\mathrm{CaCl}_{2}$ and $\mathrm{KCl}$ were used to balance potassium and calcium in all solutions. Plants were watered when the moss surface became dry.

Measurements. In Mar. and Apr. 2009, the length of the flowering period, labellum diameter, dorsal sepal diameter, petal diameter, and peduncle length were recorded for each mature plant during the flowering phase. All the diameters were measured from the point of attachment to the top using a slide caliper. Hand pollination was performed on the fifth day after bloom for 25 plants per treatment group. The emergence and number of ramets and their sizes (leaf area and leaf number) in the mature plants were determined on Sept. 2009.

The seed capsule weight was measured at 60,90 , and $120 \mathrm{~d}$ after pollination (DAP). The 120 DAP seed capsule was surface-sterilized and the seeds were scattered on the surface of 
1/4 Murashige and Skoog (MS) basal medium (Murashige and Skoog, 1962) supplemented with $30 \mathrm{~g} \cdot \mathrm{L}^{-1}$ potato mash and $\left(\mathrm{mg} \cdot \mathrm{L}^{-1}\right)$ : activated carbon (300), sucrose $(20,000)$, agar $(8,000)$, and kinetin $(0.25)$. The seed germination rates were calculated after $90 \mathrm{~d}$ incubation of seeds in a dark room at $25 \pm 1{ }^{\circ} \mathrm{C}$. The germinated protocorms were transferred on 1/2 MS medium with the previously listed supplements and cultured under a fluorescent lamp source at a photosynthetic photon flux density of $40 \mu \mathrm{mol}$ photons $/ \mathrm{m}^{2} / \mathrm{s}$ with a photoperiod of 12:12 (light: dark) at a controlled temperature $\left(24 / 18{ }^{\circ} \mathrm{C}\right.$, day/night). After 6 months cultivation, 48 seedlings of each treatment were sampled. The $\mathrm{N}$ concentration, carbon $(\mathrm{C})$ concentration, leaf number, leaf span, root number, and dry weight were measured for each plant. The $\mathrm{N}$ and $\mathrm{C}$ concentrations were determined with an automatic element analyzer (Leco FP-428, MI) after the plants had been dried to a constant mass at $70^{\circ} \mathrm{C}$ and ground to powder. The $\mathrm{pH}$ of all medium used in this experiment was adjusted to 5.8 with $1 \mathrm{~mol} \cdot \mathrm{L}^{-1} \mathrm{KOH}$ or $\mathrm{HCl}$ before it was autoclaved for $15 \mathrm{~min}$ at $121^{\circ} \mathrm{C}$.

The leaf area, leaf $\mathrm{N}$ concentration, chlorophyll content, and chlorophyll fluorescence for juvenile and mature plants were measured on Sept. 2009, after the capsules had been harvested. The numbers of new leaves and withered leaves were recorded at end of the experiment. The increase in leaf area was obtained from the difference between the start and end leaf area. The percentage increase in leaf area was the ratio between the increase in leaf area and the initial leaf area in every plant. The leaf area of each plant was the sum of products of the length and maximum width of every leaf. The $\mathrm{N}$ concentrations of the old leaves and new leaves were determined separately. The old leaves were leaves on the plants when treatments started. The initial leaf $\mathrm{N}$ concentration of the old leaves was obtained in four extra plants at the beginning of the experiment.

Four plants in each treatment were sampled for measuring the chlorophyll content. Ten leaf discs were obtained from fully expanded leaves with a $1.0-\mathrm{cm}$ hole punch and extracted with $10 \mathrm{~mL}$ of $\mathrm{N}, \mathrm{N}$-dimethylformamide at $4{ }^{\circ} \mathrm{C}$ for $72 \mathrm{~h}$. The absorbance of the extract was analyzed at 647 and $664.5 \mathrm{~nm}$ on a Shimadzu ultraviolet-2550 spectrophotometer (Shimadzu, Kyoto, Japan). The chlorophyll $\mathrm{a} / \mathrm{b}(\mathrm{Chl} \mathrm{a} / \mathrm{b})$ and chlorophyll content (Chl $\mathrm{a}+\mathrm{b})$ were calculated using the method of Inskeep and Bloom (1985).

The chlorophyll fluorescence of maximal photochemical efficiency $\left(\mathrm{F}_{\mathrm{v}} / \mathrm{F}_{\mathrm{m}}\right)$ was measured in 10 independent samples per treatment at 1000 HR on 14 Sept. 2009. The third fully expanded leaf from the bottom was dark-adapted for $45 \mathrm{~min}$, after which the $\mathrm{F}_{\mathrm{v}} / \mathrm{F}_{\mathrm{m}}$ was estimated with a pulse amplitudemodulated chlorophyll fluorescence meter (Hansatech FMS 2; Hansatech Instruments, Ltd., King's Lynn, Norfolk, U.K.).

Statistical analysis. All statistical tests were performed with SPSS 16.0 (SPSS Inc., Chicago, IL). The data were subjected to one-way analysis of variance. Ramet emergence rates were tested by chi-square test. Significant differences between $\mathrm{N}$ rates were determined with linear contrasts. Differences were considered statistically significant at a probability of $P \leq 0.05$ in all tests. Graphs were plotted with SigmaPlot 10.0 (Systat, San Jose, CA).

\section{Results}

Influence of nitrogen on vegetative growth. In juvenile plants, $\mathrm{N}$ rate did not affect total leaf number during the experiment (Fig. 1A). The HN (420 mg. $\mathrm{L}^{-1}$ ) plants produced fewer new leaves and withered leaves than other treatments as shown in Figures 1B and 1C. The percentage increase in leaf area tended to increase as more $\mathrm{N}$ was added so that the $\mathrm{HN}$ plants displayed the greater leaf area than $0 \mathrm{~N}$ as shown in Figure 1D. Although juvenile plants fertilized with $\mathrm{HN}$ had fewer new leaves and withered leaves, the leaves were larger with $\mathrm{HN}$ compared with $0 \mathrm{~N}$.

In juvenile plants, the $0 \mathrm{~N}$ and $\mathrm{LN}$ (105 $\mathrm{mg} \cdot \mathrm{L}^{-1}$ ) treatments had the lowest leaf $\mathrm{N}$ concentrations in both the new and old leaves (Table 1). Chl a/b was not different between $\mathrm{N}$ rates, whereas the effect of $\mathrm{N}$ rate on $\mathrm{Chl}$ $\mathrm{a}+\mathrm{b}$ was quite similar to those for the leaf $\mathrm{N}$ concentrations. There was almost a threefold increase in $\mathrm{Chl} \mathrm{a}+\mathrm{b}$ when $\mathrm{N}$ rate increased from $\mathrm{LN}$ to $\mathrm{MN}$. No variations were detected in $\mathrm{Chl} \mathrm{a} / \mathrm{b}$ among treatments. $0 \mathrm{~N}$ plants had the lowest $F_{\mathrm{v}} / \mathrm{F}_{\mathrm{m}}$ of 0.61 , whereas $\mathrm{F}_{\mathrm{v}} / \mathrm{F}_{\mathrm{m}}$ was 0.83 to 0.85 in the plants receiving $\mathrm{N}$.

There were no significant differences in leaf traits and chlorophyll parameters among treatments in mature plants (data not shown).
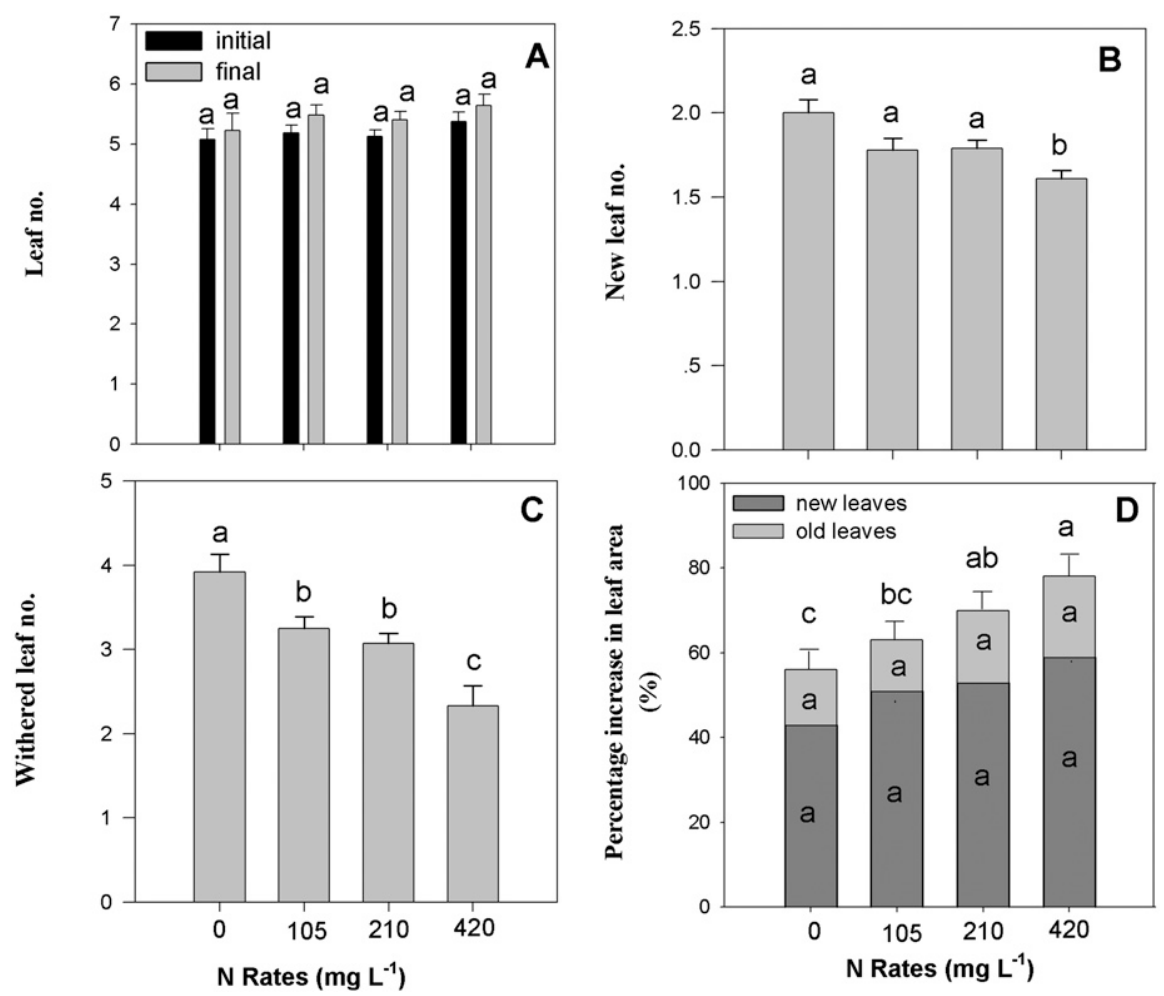

Fig. 1. Effects of nitrogen $(\mathrm{N})$ treatments on $(\mathbf{A})$ leaf number, $(\mathbf{B})$ the number of new leaves, $(\mathbf{C})$ the number of withered leaves, and (D) percentage increase in leaf area in juvenile plants. Means \pm SD are shown. Letters above the bars indicate the significance of the differences between $\mathrm{N}$ rates at $P \leq 0.05$ based on linear contrasts. Simple sizes were $43,72,67$, and 71 for the $0 \mathrm{~N}\left(0 \mathrm{mg} \cdot \mathrm{L}^{-1}\right), \mathrm{LN}\left(105 \mathrm{mg} \cdot \mathrm{L}^{-1}\right)$, MN (210 mg. $\left.\mathrm{L}^{-1}\right)$, and $\mathrm{HN}\left(420 \mathrm{mg} \cdot \mathrm{L}^{-1}\right)$ treatment groups, respectively.

Table 1. Comparisons of leaf nitrogen $(\mathrm{N})$ concentrations, leaf chlorophyll (Chl) contents, and maximal photochemical efficiency $\left(\mathrm{F}_{\mathrm{v}} / \mathrm{F}_{\mathrm{m}}\right)$ ratios for $P$. armeniacum among the four treatment groups in juvenile plants.

\begin{tabular}{lccccc}
\hline & \multicolumn{2}{c}{ Leaf N concn (\%) } & & & \\
\cline { 2 - 7 } Treatments & New leaves & Old leaves & Chl a/b & Chl a+b $\left(\mu \mathrm{g} \cdot \mathrm{cm}^{-2}\right)$ & $\mathrm{F}_{\mathrm{v}} / \mathrm{F}_{\mathrm{m}}$ \\
\hline Initial & & $1.83 \mathrm{a}$ & & & \\
$0 \mathrm{~N}\left(0 \mathrm{mg} \cdot \mathrm{L}^{-1}\right)$ & $0.70 \mathrm{~b}^{\mathrm{z}}$ & $1.23 \mathrm{~b}$ & 2.76 & $3.47 \mathrm{~b}$ & $0.61 \mathrm{~b}$ \\
$\mathrm{LN}\left(105 \mathrm{mg} \cdot \mathrm{L}^{-1}\right)$ & $0.73 \mathrm{~b}$ & $1.21 \mathrm{~b}$ & 2.73 & $5.61 \mathrm{~b}$ & $0.85 \mathrm{a}$ \\
$\mathrm{MN}\left(210 \mathrm{mg} \cdot \mathrm{L}^{-1}\right)$ & $1.13 \mathrm{a}$ & $1.89 \mathrm{a}$ & 2.74 & $16.39 \mathrm{a}$ & $0.83 \mathrm{a}$ \\
$\mathrm{HN}\left(420 \mathrm{mg} \cdot \mathrm{L}^{-1}\right)$ & $1.06 \mathrm{a}$ & $2.05 \mathrm{a}$ & 2.74 & $12.82 \mathrm{a}$ & $0.85 \mathrm{a}$ \\
Significance & $* *$ & $*$ & $\mathrm{NS}$ & $* *$ & $* *$ \\
\hline
\end{tabular}

${ }^{2}$ Mean separation within columns by linear contrasts at $P \leq 0.05$.

${ }^{\mathrm{y}}$ Significance for analysis of variance for $\mathrm{N}$ rates: ${ }^{* *} P \leq 0.05 ;{ }^{*} P \leq 0.01$; NS $=$ nonsignificant. 
Table 2. Effects of nitrogen $(\mathrm{N})$ treatments on the sexual reproduction of $P$. armeniacum.

\begin{tabular}{|c|c|c|c|c|c|c|c|c|c|}
\hline \multirow[b]{2}{*}{ Treatments } & \multicolumn{5}{|c|}{ Floral traits } & \multicolumn{3}{|c|}{ Capsule wt (g) } & \multirow[b]{2}{*}{$\begin{array}{c}\text { Seed germination } \\
\text { rate }(\%)\end{array}$} \\
\hline & $\begin{array}{l}\text { Flowering } \\
\text { time }(\mathrm{d})\end{array}$ & $\begin{array}{c}\text { Peduncle } \\
\text { length }(\mathrm{cm})\end{array}$ & $\begin{array}{l}\text { Labellum } \\
\text { diam }(\mathrm{cm})\end{array}$ & $\begin{array}{c}\text { Petal } \\
\text { diam }(\mathrm{cm})\end{array}$ & $\begin{array}{c}\text { Dorsal sepal } \\
\text { diam }(\mathrm{cm})\end{array}$ & $\begin{array}{c}60 \\
\text { DAP }\end{array}$ & $\begin{array}{c}90 \\
\text { DAP }\end{array}$ & $\begin{array}{c}120 \\
\text { DAP }\end{array}$ & \\
\hline$\overline{0 \mathrm{~N}}\left(0 \mathrm{mg} \cdot \mathrm{L}^{-1}\right)$ & $28.04 \mathrm{a}^{\mathrm{z}}$ & $17.44 \mathrm{~b}$ & 3.53 & $3.67 \mathrm{~b}$ & 3.06 & $0.64 \mathrm{~b}$ & 0.77 & $0.66 \mathrm{~b}$ & $5.44 \mathrm{~b}$ \\
\hline $\mathrm{LN}\left(105 \mathrm{mg} \cdot \mathrm{L}^{-1}\right)$ & $23.41 \mathrm{~b}$ & $21.19 \mathrm{a}$ & 3.46 & $3.61 \mathrm{~b}$ & 2.98 & $0.87 \mathrm{a}$ & 0.74 & $0.75 \mathrm{ab}$ & $2.43 \mathrm{~b}$ \\
\hline $\mathrm{MN}\left(210 \mathrm{mg} \cdot \mathrm{L}^{-1}\right)$ & $22.39 \mathrm{bc}$ & $21.90 \mathrm{a}$ & 3.52 & $3.87 \mathrm{a}$ & 3.13 & $0.86 \mathrm{a}$ & 0.81 & $0.81 \mathrm{a}$ & $22.00 \mathrm{a}$ \\
\hline $\mathrm{HN}\left(420 \mathrm{mg} \cdot \mathrm{L}^{-1}\right)$ & $20.80 \mathrm{c}$ & $21.00 \mathrm{a}$ & 3.33 & $3.52 \mathrm{~b}$ & 2.95 & $0.79 \mathrm{ab}$ & 0.71 & $0.66 \mathrm{~b}$ & $7.35 \mathrm{~b}$ \\
\hline Significance $^{\mathrm{y}}$ & $* *$ & $* *$ & NS & $* *$ & NS & $*$ & NS & $*$ & $* *$ \\
\hline
\end{tabular}

${ }^{\mathrm{z}}$ Mean separation within columns by linear contrasts at $P \leq 0.05$.

${ }^{\mathrm{y}}$ Significance for analysis of variance for $\mathrm{N}$ rates: $* * P \leq 0.05 ; * P \leq 0.01$; NS $=$ nonsignificant.

$\mathrm{DAP}=$ days after pollination .

Influence of nitrogen on reproduction. During the reproductive stage, $0 \mathrm{~N}$ plants presented longer flower time $(28.04 \mathrm{~d})$ and shorter peduncle length $(17.44 \mathrm{~cm})$ compared with $\mathrm{N}$-fertilized plants (Table 2). Flower size was evaluated by the diameters of the labellum, petal, and dorsal sepal, and it varied little among all treatments. Capsule weight in the $0 \mathrm{~N}$ group was lowest at $60 \mathrm{DAP}$ but tended to be the same as other $\mathrm{N}$ treatments at 90 DAP. Afterward, capsule weight was the lowest in the $0 \mathrm{~N}-$ and LN-treated plants at 120 DAP. The seed germination rate of $\mathrm{MN}$-treated plants was markedly higher $(22.00 \%)$ than those produced by the other treatments, which were only $7.35 \%$ or less. For seedlings developed from seeds of different treatment, the $\mathrm{N}$ concentration, $\mathrm{C}$ concentration, leaf span, root number, and dry weight were generally increased with increasing $\mathrm{N}$ application (Table 3).

The emergence and number of ramet were unaffected by the $\mathrm{N}$ input, whereas the leaf number and leaf area of ramet reacted differently to the $\mathrm{N}$ concentrations (Table 4). The leaf number and leaf area of ramet in the $\mathrm{LN}$ treatment group were 3.03 and $4.07 \mathrm{~cm}^{2}$, respectively, which were more than twice those in the $0 \mathrm{~N}$ treatment group $\left(1.06\right.$ and $1.73 \mathrm{~cm}^{2}$, respectively). Leaf number and leaf area of ramet tended to decrease when the application of $\mathrm{N}$ was doubled from $\mathrm{LN}$ to $\mathrm{MN}$ and from $\mathrm{MN}$ to $\mathrm{HN}$.

\section{Discussion}

Influence of nitrogen on vegetative growth. Mature plants displayed little response to $\mathrm{N}$ fertilization on leaf traits and chlorophyll parameters, because vegetative growth is drastically reduced in the reproductive stage (Obeso, 2002; Onate and Munne-Bosch, 2009). In the $\mathrm{N}$-deficient juvenile plants of $P$. armeniacum, the low substrate $\mathrm{N}$ availability and excessive $\mathrm{N}$ demand by the new leaves accelerated leaf shedding, resulting in a shorter leaf lifespan and more withered leaves compared with $\mathrm{N}$ sufficient plants. The leaf lifespan has been known to increase in response to an increased N supply (Ono et al., 1996, 2001; Thomas and de Villiers, 1996), and similar results were found in our study in which the MN and $\mathrm{HN}$ plants had a longer leaf lifespan than $0 \mathrm{~N}$ and LN plants. In our study, $\mathrm{N}$ fertilizer increased leaf area during vegetative growth, which was similar to previous work on other ornamental orchids (Bichsel et al., 2008; Kubota et al., 2009; Wang, 1996; Wang and Gregg, 1994).

Table 3. Growth of seedlings developed from seeds of N-treated plants of P. armeniacum.

\begin{tabular}{lcccccc}
\hline Treatments & N concn $(\%)$ & C concn $(\%)$ & Leaf no. & Leaf span $(\mathrm{cm})$ & Root no. & Dry wt $(\mathrm{mg})$ \\
\hline $\mathrm{ON}\left(0 \mathrm{mg} \cdot \mathrm{L}^{-1}\right)$ & $1.64 \mathrm{~d}^{\mathrm{z}}$ & $42.92 \mathrm{~b}$ & 5.00 & $1.59 \mathrm{c}$ & $1.42 \mathrm{c}$ & $6.53 \mathrm{c}$ \\
$\mathrm{LN}\left(105 \mathrm{mg} \cdot \mathrm{L}^{-1}\right)$ & $2.25 \mathrm{c}$ & $43.19 \mathrm{~b}$ & 4.75 & $1.96 \mathrm{~b}$ & $2.31 \mathrm{~b}$ & $7.21 \mathrm{c}$ \\
$\mathrm{MN}\left(210 \mathrm{mg} \cdot \mathrm{L}^{-1}\right)$ & $2.45 \mathrm{bc}$ & $44.09 \mathrm{ab}$ & 4.46 & $2.09 \mathrm{bc}$ & $3.38 \mathrm{a}$ & $13.12 \mathrm{~b}$ \\
$\mathrm{HN}\left(420 \mathrm{mg} \cdot \mathrm{L}^{-1}\right)$ & $2.78 \mathrm{a}$ & $46.38 \mathrm{a}$ & 4.68 & $3.03 \mathrm{a}$ & $3.17 \mathrm{a}$ & $23.32 \mathrm{a}$ \\
Significance & $* *$ & $*$ & NS & $* *$ & $* *$ & $* *$ \\
\hline
\end{tabular}

${ }^{\mathrm{z}}$ Mean separation within columns by linear contrasts at $P \leq 0.05$

${ }^{\mathrm{y}}$ Significance for analysis of variance for $\mathrm{N}$ rates: $* * P \leq 0.05 ;{ }^{*} P \leq 0.01$; NS $=$ nonsignificant. $\mathrm{N}=$ nitrogen; $\mathrm{C}=$ carbon.

Table 4. Influence of nitrogen $(\mathrm{N})$ treatments on the clonal reproduction of $P$. armeniacum.

\begin{tabular}{lccccc}
\hline Treatments & $\mathrm{n}$ & Ramet emergence & Ramet no. per plant & Ramet leaf no. & Ramet leaf area $\left(\mathrm{cm}^{2}\right)$ \\
\hline ON $\left(0 \mathrm{mg} \cdot \mathrm{L}^{-1}\right)$ & 34 & 0.72 & 1.35 & $1.06 \mathrm{~b}^{\mathrm{z}}$ & $1.73 \mathrm{~b}$ \\
$\mathrm{LN}\left(105 \mathrm{mg} \cdot \mathrm{L}^{-1}\right)$ & 38 & 0.78 & 1.55 & $3.03 \mathrm{a}$ & $4.07 \mathrm{a}$ \\
$\mathrm{MN}\left(210 \mathrm{mg} \cdot \mathrm{L}^{-1}\right)$ & 36 & 0.80 & 1.56 & $1.97 \mathrm{ab}$ & $3.13 \mathrm{ab}$ \\
$\mathrm{HN}\left(420 \mathrm{mg} \cdot \mathrm{L}^{-1}\right)$ & 33 & 0.74 & 1.58 & $2.12 \mathrm{ab}$ & $2.57 \mathrm{ab}$ \\
Significance & & $\mathrm{NS}^{\mathrm{y}}$ & $\mathrm{NS}$ & $* *$ & $*$ \\
\hline
\end{tabular}

${ }^{\mathrm{z}}$ Mean separation within columns by linear contrasts at $P \leq 0.05$.

${ }^{y}$ Differences between ramet emergence rates were determined by chi-square test at $P \leq 0.05$ with a $P$ value of 0.834 .

${ }^{\mathrm{x}}$ Significance for analysis of variance for $\mathrm{N}$ rates: $* * P \leq 0.05 ; * P \leq 0.01$; NS $=$ nonsignificant.

Leaf $\mathrm{N}$ concentration, chlorophyll content, and chlorophyll fluorescence can be used as effective parameters to evaluate plant photosynthesis. $\mathrm{N}$ deficiency led to decreases in both leaf $\mathrm{N}$ concentration and chlorophyll content in $0 \mathrm{~N}$ and $\mathrm{LN}$ plants. The $\mathrm{F}_{\mathrm{v}} / \mathrm{F}_{\mathrm{m}}$ ratio is often used as an indicator of the maximum photochemical efficiency of photosystem II and is typically in the range of 0.75 to 0.85 for unstressed plants (Bjorkman and Demmig, 1987). The deficiency of $\mathrm{N}$ usually leads to low $\mathrm{F}_{\mathrm{v}} / \mathrm{F}_{\mathrm{m}}$ (Magnusson, 1997; Pompelli et al., 2010). In our study, $0 \mathrm{~N}$ plants suffered obvious stress with the low $F_{v} / F_{m}$ value of 0.61 , manifesting an impairment of photosynthesis. $\mathrm{MN}-$ fertilized plants had greater leaf $\mathrm{N}, \mathrm{Chl}$, and $F_{\mathrm{v}} / \mathrm{F}_{\mathrm{m}}$ than $\mathrm{LN}$-fertilized plants without the higher fertilizer and environmental cost of a $\mathrm{HN}$ regime. According to the performances of juvenile plants under different $\mathrm{N}$ concentrations, $210 \mathrm{mg} \cdot \mathrm{L}^{-1} \mathrm{~N}$ was recommended for the cultivation of seedlings of $P$. armeniacum to obtain robust plants.

Influence of nitrogen on reproduction. $0 \mathrm{~N}$ treatment increased flowering time without decreasing flower size but did shorten peduncle length in $P$. armeniacum. Flower size responded little to $\mathrm{N}$ fertilization, mostly because the flower organ development began late in August and the biomass accumulation in the flower organ slowed by the middle of November (Pi, 2009). Because the N fertilization started in November, the variations in external $\mathrm{N}$ in the slow growth stage of the flower organ probably did not affect the floral traits much. It seems that short-term $\mathrm{N}$ fertilization before bloom does not regulate flower size in ornamental orchids (Bichsel et al., 2008; Wang, 1996; Wang and Gregg, 1994). $\mathrm{N}$ fertilizer might have more influence on flower traits at an earlier stage of flower induction and development; however, further investigation needs to be undertaken. Leaf numbers of $P$. armeniacum were positively correlated with flower size (Pearson's correlation coefficients were $0.148,0.196,0.188$, and 0.151 to labellum diameter, dorsal sepal diameter, petal diameter, and peduncle length, respectively (Z.M. Mou, unpublished data); thus, the regulation of plant size may be a potential way to improve flower quality in the future.

Asymbiotic cultivation of seeds is the main way to obtain new plants of $P$. armeniacum, because the tissue culture protocols have not been determined for this species. The seed germination rate of $P$. armeniacum was extremely low, not more than $26 \%$ after 4 weeks cultivation on the most suitable culture medium (Chen et al., 2004). Therefore, enhancing the quantity and quality of seeds is needed for commercial production of $P$. armeniacum. Fertilization generally increases seed quality (seed weight and viability) and production in perennial herbs (Breen and Richards, 2008; Dwivedi et al., 1999; O’Donovan et al., 2011). 
In our study, $210 \mathrm{mg} \cdot \mathrm{L}^{-1} \mathrm{~N}(\mathrm{MN})$ addition brought the heaviest capsules, highest seed germination rate, and vigorous seedlings. Although the dry weight of seedlings propagated from seeds in $\mathrm{HN}$-treated plants was highest of all, the seed germination rate was much lower of HN-treated plants than MN-treated plants. Thus, excessive $\mathrm{N}$ input is unnecessary for seed production of $P$. armeniacum. Other researchers working with other orchids have also showed the inhibitory effects of large quantities of $\mathrm{N}$ on reproductive development (Duan and Yazawa, 1995; Lindhard and Hansen, 1997; Wang, 2003).

Cultivation of ramets is another way to obtain new plants of $P$. armeniacum when asymbiotic germination on axenic culture medium is unavailable. A tradeoff is observed between sexual and clonal reproduction in $P$. armeniacum, and the two reproductive patterns compete for resources under natural conditions ( $\mathrm{Pi}, 2009)$. Clonal species always increase the allocation of dry weight to clonal reproduction under resource limitation (Abrahamson, 1980). The LN (105 mg. $\left.\mathrm{L}^{-1}\right)$ condition produced larger ramets than $0 \mathrm{~N}$ but was not different from $\mathrm{MN}$ and $\mathrm{HN}$. The lower $\mathrm{N}$ requirements for clonal reproduction than sexual reproduction can also account for larger ramets at the low $\mathrm{N}$ level, because reproductive dry weight allocation was used for ramet growth. When the $\mathrm{N}$ concentration rose from $\mathrm{LN}$ to $\mathrm{MN}$, more resources were allocated to sexual reproduction (seed viability and production), leading to a sharp increase in the seed germination rate and producing bigger seedlings. The allocation under the highest $\mathrm{N}$ concentrations was complicated because both reproductive patterns had been reduced compared with their best performances, respectively.

In summary, the medium level of $\mathrm{N}$ of 210 $\mathrm{mg} \cdot \mathrm{L}^{-1}$ improved growth of juvenile plants and also seed production and viability of mature plants, generating more vigorous seedlings. Lower $\mathrm{N}$ concentration of $105 \mathrm{mg} \cdot \mathrm{L}^{-1}$ promoted the growth of ramets. The $\mathrm{N}$ levels of $P$. armeniacum in production and cultivation should be determined according to different production objectives.

\section{Literature Cited}

Abrahamson, W.G. 1980. Demography and vegetative reproduction. Blackwell, Oxford, UK.

Breen, A.N. and J.H. Richards. 2008. Irrigation and fertilization effects on seed number, size, germination and seedling growth: Implications for desert shrub establishment. Oecologia 157:13-19.
Bichsel, R.G., T.W. Starman, and Y.T. Wang. 2008. Nitrogen, phosphorus, and potassium requirements for optimizing growth and flowering of the nobile Dendrobium as a potted orchid. HortScience 43:328-332.

Bjorkman, O. and B. Demmig. 1987. Photon yield of $0_{2}$ evolution and chlorophyll fluorescence characteristics at $77 \mathrm{~K}$ among vascular plants of diverse origins. Planta 170:489-504.

Boussadia, O., K. Steppe, H. Zgallai, S.B.E.I. Hadj, M. Brahan, R. Lemeur, and M.C. Van Labeke. 2010. Effects of nitrogen deficiency on leaf photosynthesis, carbohydrate status and biomass production in two olive cultivars 'Meski' and 'Koroneiki'. Sci. Hort. 123:336-342.

Chapin, F.S., C.H.S. Walter, and D.T. Clarkson. 1988. Growth response of barley and tomato to nitrogen stress and its control by abscisic acid, water relations and photosynthesis. Planta 173:352-366.

Chen, Z.L., X.L. Ye, C.Y. Liang, and D. June. 2004. Seed Germination in vitro of Paphiopedilum armeniacum and $P$. micranthum. . Acta. Hort. Sin. 31:540-542.

Cribb, P. 1998. The genus Paphiopedilum. 2nd Ed. Natural History, Borneo, London.

Duan, J.X. and S. Yazawa. 1995. Floral induction and development in Phalaenopsis in vitro. Plant Cell Tissue Organ Cult. 43:71-74.

Dwivedi, G.K., D. Kumar, and P.S. Tomer. 1999. Effect of cutting management and nitrogen levels on growth, seed yield attributes and seed production of Setaria sphacelata cv. Nandi. Trop. Grasslands 33:146-149.

Ferrar, P.J. and C.B. Osmond. 1986. Nitrogen supply as a factor influencing photoinhibition and photosynthetic acclimation after transfer of shade-grown Solanum dulcamara to bright light. Planta 168:563-570.

Hoagland, D.R. and D.I. Arnon. 1950. The water culture method for growing plants without soil. Calif. Agr. Expt. Sta., Univ. of Calif., Berkeley Circ. 347.

Inskeep, W.P. and P.R. Bloom. 1985. Extinction coefficients of chlorophyll $a$ and $b$ in $\mathrm{N}, \mathrm{N}$ dimethylformamide and $80 \%$ acetone. Plant Physiol. 77:483-485.

Kubota, S., Y. Muramatsu, M. Matsuura, M. Ito, H. Suniyoshi, and M. Koshioka. 2009. The growth and flowering of Odontioda orchid are stimulated by nitrogen application. Hort. Res. (Japan) 8:175-180.

Lindhard, P.H. and P. Hansen. 1997. Effect of timing of nitrogen supply on growth, bud, flower and fruit development of young sour cherries (Prunus cerasus L). Sci. Hort. 69:181-188.

Magnusson, G. 1997. Diurnal measurements of $\mathrm{F}_{\mathrm{v}} / \mathrm{F}_{\mathrm{m}}$ used to improve productivity estimates in macroalgae. Mar. Biol. 130:203-208.

Munoz, A.A., C. Celedon-Neghme, L.A. Cavieres, and M.T.K. Arroyo. 2005. Bottom-up effects of nutrient availability on flower production, pollinator visitation, and seed output in a highAndean shrub. Oecologia 143:126-135.
Murashige, T. and F. Skoog. 1962. A revised medium for rapid growth and bioassays with tobacco tissue culture. Physiol. Plant. 15:473-479.

Obeso, J.R. 2002. The costs of reproduction in plants. New Phytol. 155:321-348.

O’Donovan, J.T., T.K. Turkington, and M.J. Edney. 2011. Seeding rate, nitrogen rate, and cultivar effects on malting barley production. Agron. J. 103:709-716.

Onate, M. and S. Munne-Bosch. 2009. Influence of plant maturity, shoot reproduction and sex on vegetative growth in the dioecious plant Urtica dioica. Ann. Bot. (Lond.) 104:945-956.

Ono, K., I. Terashima, and A. Watanabe. 1996. Interaction between nitrogen deficit of a plant and nitrogen content in the old leaves. Plant Cell Physiol. 37:1083-1089.

Ono, K., Y. Nishi, A. Watanabe, and I. Terashima. 2001. Possible mechanisms of adaptive leaf senescence. Plant Biol. 3:234-243.

Paul, M.J. and S.P. Driscoll. 1997. Sugar repression of photosynthesis: The role of carbohydrates in signalling nitrogen deficiency through source: sink imbalance. Plant Cell Environ. 20:110-116.

Pompelli, M.F., S.C.V. Martins, W.C. Antunes, and A.R.M. Chaves. 2010. Photosynthesis and photoprotection in coffee leaves is affected by nitrogen and light availabilities in winter conditions. J. Plant Physiol. 167:1052-1060.

Pi, Q.X. 2009. The flower development of Paphiopedilum armeniacum (Orchidaceae). Chin. Acad. Sci. Master diss. Abstr. 10001200628010615018.

Thomas, H. and L. de Villiers. 1996. Gene expression in leaves of Arabidopsis thaliana induced to senesce by nutrient deprivation. J. Expt. Bot. 47:1845-1852.

Tsi, Z.H., Y.B. Lou, P.J. Cribb, N. McGough, S. Gloria, and C. Lawrence. 1999. A preliminary report on the population size, ecology, and conservation status of some Paphiopedilum species (Orchidaceae) in southwest China. Lindleyana 14:12-23.

Wang, Y.T. 1996. Effects of six fertilizers on vegetative growth and flowering of Phalaenopsis orchids. Sci. Hort. 65:191-197.

Wang, Y.T. 2003. Effects of $\mathrm{N}$ and $\mathrm{P}$ concentration on growth and flowering of the Phalaenopsis orchid. HortScience 38:746-747.

Wang, Y.T. and L.L. Gregg. 1994. Medium and fertilizer affect the performance of Phalaenopsis orchids during two flowering cycles. HortScience 29:269-271.

Yoneda, K., N. Suzuki, and I. Hasegawa. 1999. Effects of macroelement concentrations on growth, flowering, and nutrient absorption in an Odontoglossum hybrid. Sci. Hort. 80:259-265.

Zotz, G. 2004. The resorption of phosphorus is greater than that of nitrogen in senescing leaves of vascular epiphytes from lowland Panama. J. Trop. Ecol. 20:693-696.

Zotz, G. and R. Asshoff. 2010. Growth in epiphytic bromeliads: Response to the relative supply of phosphorus and nitrogen. Plant Biol. 12:108111. 